\title{
Measuring the determinants of business cycle synchronization using a panel approach ${ }^{\hat{v}}$
}

\author{
Pedro André Cerqueira *, Rodrigo Martins \\ Faculty of Economics, University of Coimbra, Portugal
}

\section{A R T I C L E I N F O}

\section{Article history:}

Received 20 November 2007

Received in revised form 21 November 2008

Accepted 22 November 2008

Available online 3 December 2008

\section{Keywords:}

Business cycles synchronization

Panel data

JEL classification:

C23

E32

\begin{abstract}
A B S T R A C T
This paper investigates the GDP synchronization determinants using a new index for panel data that captures time variability effects. Although most of our evidence is in line with previous studies, the effect of financial openness differs from the standard findings.
\end{abstract}

(c) 2008 Elsevier B.V. All rights reserved.

\section{Introduction}

There is a long-standing interest in understanding which variables can explain why some countries are more synchronized than others. Until now different channels have been purposed and evaluated with mixed results.

The first is bilateral trade. Empirical studies, such as those by Frankel and Rose (1998), Clark and van Wincoop (2001), Baxter and Koupiratsas (2004) and Imbs (2004, 2006), provide evidence that countries with higher levels of bilateral trade also have higher business cycle synchronization.

Industrial structure and specialization are also used. Countries with a more similar industrial structure should be more synchronous. Even though Imbs $(2004,2006)$ findings go in this direction, Baxter and Koupiratsas (2004) find that this hypothesis is not robust and Clark and van Wincoop (2001) find that this relationship is not significant.

Also the financial channel is exploited. Agents of less financially integrated countries cannot use the mechanisms of international risksharing ${ }^{1}$ limiting the transfer of resources across countries and forcing

\footnotetext{
is We would like to thank the comments of Elias Soukiazis and an anonymous referee. The usual disclaimer applies.

* Corresponding author. Faculty of Economics, University of Coimbra, Av. Dias da Silva, 165, 3004-512 Coimbra, Portugal. Tel.: +351 239790 500; fax: +351 239790514 E-mail address: pacerq@fe.uc.pt (P.A. Cerqueira).

1 See the papers of Arreaza et al. (1998) and Sorensen and Yosha (1998a,b).
}

agents to investment domestically, rather than exploiting the best opportunities worldwide, thus increasing the GDP's cross-correlation. But, liquidity constraints, imperfect information or regulatory limits to capital flows (indicators of poor financial integration) may lead foreign investors to withdraw capital, reducing investment, GDP and the cross-correlations with other countries. Imbs $(2004,2006)$ finds that more financially integrated countries are more synchronous (the second effect seems to be dominant) and Kose et al. (2003) find that financially open developing economies have synchronized cycles with the G7 countries.

Other variables have been used, namely, belonging to a currency union or a trade agreement, distance between two countries, degree of development, similarity of exports and imports, etc.

However, to the best of our knowledge, previous papers use the cross-correlation of the GDP between countries for a certain time span and averaging over time the other variables. Therefore, the estimations are cross-sectional, or at most, panels with few observations over time as some compute the previous cross-correlations and averages for several sub-periods. This data aggregation minimizes the importance of time variability.

We consider that the use of more disaggregated data over time can give a better understanding of the subject. For that we develop a synchronization index that enables us to use panel data techniques without any aggregation over time.

The structure of the paper is the following: the next section describes the data details and the synchronization index used, the following presents and discusses the results and the final one concludes. 


\section{Data and measurement}

The data used were the GDP, the production in value added by the ISIC code $^{2}$ at one digit, total imports and exports from the OECD database 2006 and financial openness from Lane and Milesi-Ferretti (2006) for twenty OECD countries from 1970 to $2002^{3}$.

The typical cross-section regression used by previous studies is:

$\rho_{i j}=F\left(\sum_{t=1}^{T} \frac{X_{i j, t}}{T}, \sum_{t=1}^{T} \frac{u_{i j, t}}{T}\right)$

where $\rho_{i j}$ represents the GDP cross correlation index between country $i$ and $j, X_{i j, t}$ is a vector of the explanatory variables and $u_{i j, t}$ are the stochastic shocks.

With this methodology we lose the time variability. To capture this, a panel data model is more suitable, but a synchronization indicator at all points in time $\left(\rho_{i j, t}\right)$ is needed in order to estimate the following equation:

$\rho_{i j, t}=F\left(X_{i j, t}, u_{i j, t}\right)$

Averaging over time Eq. (2) we obtain the cross-section model of Eq. (1). is:

The question is how to obtain $\rho_{i j, t}$. As $\rho_{i j}$, for a generic variable $d$,

$$
\rho_{i j}=\frac{2 \cdot \sum_{t=1}^{T}\left(\left(d_{i, t}-\bar{d}_{i}\right)\left(d_{j, t}-\bar{d}_{j}\right)\right)}{2 \cdot \sqrt{\sum_{t=1}^{T}\left(d_{i, t}-\bar{d}_{i}\right)^{2}} \sqrt{\sum_{t=1}^{T}\left(d_{j, t}-\bar{d}_{j}\right)^{2}}}
$$

by adding and subtracting 2 and manipulating the sums we get:

$\rho_{i j}=\frac{1}{2}\left(2-\sum_{t=1}^{T}\left(\frac{\left(d_{j, t}-\bar{d}_{j}\right)}{\sqrt{\sum_{t=1}^{T}\left(d_{j, t}-\bar{d}_{j}\right)^{2}}}-\frac{\left(d_{i, t}-\bar{d}_{i}\right)}{\sqrt{\sum_{t=1}^{T}\left(d_{i, t}-\bar{d}_{i}\right)^{2}}}\right)^{2}\right)$

multiplying and dividing the square by $T$ and rearranging terms we get:

$\rho_{i j}=\frac{1}{T} \sum_{t=1}^{T}\left(1-\frac{1}{2}\left(\frac{\left(d_{j, t}-\bar{d}_{j}\right)}{\sqrt{\frac{1}{T} \sum_{t=1}^{T}\left(d_{j, t}-\bar{d}_{j}\right)^{2}}}-\frac{\left(d_{i, t}-\bar{d}_{i}\right)}{\sqrt{\frac{1}{T} \sum_{t=1}^{T}\left(d_{i, t}-\bar{d}_{i}\right)^{2}}}\right)^{2}\right)$

\footnotetext{
${ }^{2}$ We build the industrial structure similarity index using the following aggregation of the ISIC codes: 0+1 -Food and live animals + Beverages and Tobacco; 2+4 - Crude materials, except fuels, animal and vegetal oils, fats and waxes+Animal and Vegetal oils, fats and waxes; 3 - Mineral fuels; 5+6+8+9 - Chemical and related+Manufactured goods + Miscellaneous manufactured+Commodities and transactions articles and 7 - Machinery and transport equipment. We used these code aggregations in order to have the maximum observations by country and time span.

3 The countries are Australia, Austria, Canada, Denmark, Finland, France, Germany, Greece, Iceland, Ireland, Italy, Japan, the Netherlands, Norway, Portugal, Spain, Sweden, Switzerland, the UK and the USA.

For the industrial similarity index the data availability ranges from 1990-2002 for Ireland to 1970-2002 for Denmark, Italy and Norway, and there is no data for France, Iceland and Portugal. Regarding the remaining variables we have data for all countries from 1970 to 2002, except for Portugal that starts in 1972.
}

therefore:

$\rho_{i j}=\sum_{t=1}^{T} \frac{\rho_{i j, t}}{T}$ and

$\rho_{i j, t}=1-\frac{1}{2}\left(\frac{\left(d_{j, t}-\bar{d}_{j}\right)}{\sqrt{\frac{1}{T} \sum_{t=1}^{T}\left(d_{j, t}-\bar{d}_{j}\right)^{2}}}-\frac{\left(d_{i, t}-\bar{d}_{i}\right)}{\sqrt{\frac{1}{T} \sum_{t=1}^{T}\left(d_{i, t}-\bar{d}_{i}\right)^{2}}}\right)^{2}$.

In this context $\rho_{i j}$ is the average value of $\rho_{i j, t}$, where $d_{j, t}$ and $d_{i, t}$ are the GDP growth rates of countries $i$ and $j$.

This index, by capturing time variability, has one main advantage over the correlation index computed over the entire period: it distinguishes negative correlations due to episodes in single years, asynchronous behavior in turbulent times and synchronous behavior over stable periods. Rolling windows is an alternative way to capture the time variability. However the correlation index has some advantages. First there is no need to set a window span, second there is no loss of observations, third it does not exhibit the so called "ghost features", as the impact of a major shock is not reflected in $n$ consecutive periods, with $n$ being the window span. Moreover, the major disadvantage with the use of overlapping windows is that the resulting variables are heavily autocorrelated and, thus, difficult to handle in econometric analysis.

Concerning the explanatory variables we include the channels found to be more robust in the literature: trade, specialization and financial openness.

Regarding the trade channel we use a bilateral trade intensity index based in the Deardorff (1998) model, given by:

Bilateral Trade $_{i j, t}=\frac{\operatorname{Exp}_{i j, t}+I m p_{i j, t}}{G D P_{i, t} G D P_{j, t}} \times \frac{G D P_{w, t}}{2}$

where $\operatorname{Exp}_{i j, t}$ are the exports from country $i$ to $j, \operatorname{Imp}_{i j, t}$ are the imports of country $i$ from $j$ and $G D P_{w, t}$ is the World's GDP ${ }^{4}$ at time $t$.

To capture the industrial structure we use a similarity index given by:

$s_{i j, t}=\sum_{k=1}^{n}\left|s_{i, t}^{k}-s_{j, t}^{k}\right|, k \neq i \wedge k \neq j$

where $s_{i, t}^{k}$ represents the weight of sector $k$ in the GDP of country $i$, at time $t$. This index varies between a minimum of 0 (complete similarity between countries) and a maximum of 2 (completely different structures).

For the financial channel we use a measure of financial openness given by:

Financial Openness $i_{i j, t}=\left(\frac{A_{i, t}+L_{i, t}}{G D P_{i, t}}+\frac{A_{j, t}+L_{j, t}}{G D P_{j, t}}\right)$

where $A_{i, t}$ and $L_{i, t}$ are total assets and liabilities of country $i$, at time $t$.

Finally we introduce dichotomous variables to access if two countries were at time $t$ simultaneously members of the same trade area agreement: EEC (later EU) or NAFTA.

\section{Estimations and results}

This section presents the regressions results. We use the Blundell and Bond (1998) GMM methodology in order to unveil and solve potential problems of endogeneity. We use the openness index as instrument for

\footnotetext{
${ }^{4}$ As a proxy for the World's GDP we use the OECD's GDP.
} 
Table 1

Synchronization channels - panel results 1970-2002

\begin{tabular}{|c|c|c|c|c|c|}
\hline & \multicolumn{3}{|c|}{ Unbalanced panel } & \multicolumn{2}{|c|}{ Balanced panel } \\
\hline & $\mathrm{FE}$ & FE & GMM & $\mathrm{FE}$ & GMM \\
\hline & $(1)$ & $(2)$ & (3) & $(4)$ & (5) \\
\hline Constant & $\begin{array}{l}1.08 * * \\
(2.48)\end{array}$ & $\begin{array}{l}2.67 * * * \\
(3.31)\end{array}$ & $\begin{array}{l}2.189 * * * \\
(4.175)\end{array}$ & $\begin{array}{l}0.894^{* * *} \\
(2.07)\end{array}$ & $\begin{array}{l}3.295^{* * * *} \\
(4.33)\end{array}$ \\
\hline $\begin{array}{l}\text { Bilateral trade } \\
\text { intensity }\end{array}$ & $\begin{array}{l}0.047 \\
(1.06)\end{array}$ & $\begin{array}{l}0.272^{* * *} \\
(2.88)\end{array}$ & $\begin{array}{l}0.0572^{* *} \\
(1.96)\end{array}$ & $\begin{array}{l}0.056 \\
(1.27)\end{array}$ & $\begin{array}{l}0.073^{* *} \\
(2.00)\end{array}$ \\
\hline Industrial similarity & & $\begin{array}{l}-0.030 \\
(-0.28)\end{array}$ & & $\begin{array}{l}-0.138 * * * \\
(-3.06)\end{array}$ & $\begin{array}{l}-0.111 \\
(-0.80)\end{array}$ \\
\hline Financial openness & $\begin{array}{l}-0.378^{* * *} \\
(-4.29)\end{array}$ & $\begin{array}{l}-0.593 * * * \\
(-4.43)\end{array}$ & $\begin{array}{l}-0.363 * * * \\
(-3.37)\end{array}$ & $\begin{array}{l}-0.374 * * * \\
(-4.30)\end{array}$ & $\begin{array}{l}-0.657 * * * \\
(-4.20)\end{array}$ \\
\hline EU & $\begin{array}{l}0.137^{* *} \\
(2.44)\end{array}$ & $\begin{array}{l}0.082 \\
(0.98)\end{array}$ & $\begin{array}{l}0.127^{* * *} \\
(2.70)\end{array}$ & $\begin{array}{l}0.134^{* *} \\
(2.38)\end{array}$ & $\begin{array}{l}0.151^{* * *} \\
(2.74)\end{array}$ \\
\hline NAFTA & $\begin{array}{l}-0.202 \\
(-0.59)\end{array}$ & $\begin{array}{l}-0.135 \\
(-0.35)\end{array}$ & $\begin{array}{l}0.115 \\
(1.64)\end{array}$ & $\begin{array}{l}-0.221 \\
(-0.65)\end{array}$ & $\begin{array}{l}-0.015 \\
(-0.15)\end{array}$ \\
\hline Observations & 6061 & 2601 & 5700 & 6080 & 5890 \\
\hline $\begin{array}{l}\text { Arellano-Bond test for } \\
\text { AR(1) }\end{array}$ & - & - & $\begin{array}{l}-9.58 \\
{[0.00]}\end{array}$ & - & $\begin{array}{l}-9.68 \\
{[0.00]}\end{array}$ \\
\hline $\begin{array}{l}\text { Arellano-Bond test for } \\
\text { AR(2) }\end{array}$ & - & - & $\begin{array}{l}-0.62 \\
{[0.54]}\end{array}$ & - & $-0.11[0.91]$ \\
\hline Groups/instruments & $190 /-$ & $136 /-$ & $190 / 185$ & $190 /-$ & $190 / 185$ \\
\hline Hansen test & - & - & $167.1[0.15]$ & - & $167.1[0.14]$ \\
\hline
\end{tabular}

$*, * *, * * *$-Coefficients significant at $10 \%, 5 \%$ and $1 \%$ respectively.

Number in curved brackets are the t-ratios; numbers in square brackets are p-values. All the regressions include a complete set of time-dummies.

The GMM estimations include lags of the dependent variable.

trade intensity between countries $i$ and $j^{5}$. Because of the lack of observations to estimate a suitable GMM model when we introduce the industrial similarity index, we perform, also, estimations with a balanced panel by computing the missing data using the multiple imputation algorithm developed by Honaker and King (2007). Finally, all economic variables, other than the synchronization index are in logs.

Table 1 presents the fixed effects and GMM estimation results using the purposed index as the dependent variable. Like other correlations measures, this index may suffer from measurement errors that lead to a larger error variance. But, as it is reasonable to assume that this measurement error and the explanatory variables are orthogonal, the assumptions needed to keep the desirable large-sample proprieties are not altered ${ }^{6}$.

Bilateral trade intensity has the expected positive sign across regressions confirming that more trade between two countries induces higher bilateral synchronization. The differences in the significance levels across regressions seem to be related with endogeneity problems in this panel framework. When controlling for these problems with the GMM the point estimates are significant and in line with those found by Frankel and Rose (1998) and Clark and van Wincoop (2001).

Concerning industrial similarity, although the estimated coefficient is negative (more similar countries have higher synchronization), once we control for endogeneity this variable fails to explain the dependent variable, confirming most of the previous studies.

Contrary to Imbs we found a negative and significant effect of financial openness. This result is in line with the international risk sharing theory. Agents from financially integrated countries have access to international risk sharing mechanism, leading nations to specialize in different sectors. However we should point out that in our results the level of industrial similarity does not explain the cross-country GDP synchronization, leading us to believe that this effect through specialization might not be the transmission channel from financial integration to synchronization. A

\footnotetext{
${ }^{5}$ We also tried the sum of the GDP per capita of each pair of countries as instrument for trade intensity and industrial specialization and the GDP per capita distance between them, given by: GDP distance $e_{i, j, t}=\left\{\frac{G D P_{t}^{i}}{G D P_{t}^{j}} \frac{G D P_{t}^{i}}{G D P_{t}^{i}}\right\}$ as instrument for industrial specialization, without significant changes in our results.

Previous studies have used other instruments, such as common border, distance or common language. However these variables are invariant over time and therefore they will be captured by the constant term of the fixed-GMM estimator.

${ }^{6}$ See, e.g., Woolridge (2002), chap. 4.
}

more suitable explanation, would be that, if countries are more financially integrated, investment flows faster between them as agents try to exploit short and medium term advantages. These flows of capital, as predicted by the finance literature, benefit countries, that due to transitory idiosyncratic shocks, exhibit higher capital returns ${ }^{7}$, boosting even more their economic performance at the expense of investment and growth in other countries. This increases business cycle volatility and reduces cross-country synchronization.

A final point regarding financial openness is why our results are different from previous research. As previous studies set this relation in a cross-section environment, the positive effect of financial openness can be seen as a proxy of long-run institutional factors favouring financial integration and synchronization. Differently, in our panel framework, the long-run factors are captured by the fixed effects (in the FE or GMM regressions) as the estimated coefficients capture the time variability effect of the variable. Therefore, it seems that each approach gives a different perspective on the effects of financial integration.

Finally, the use of panel data enables us to control for economic integration areas more accurately because we can pinpoint the country's year of entrance. Only EU membership has a positive effect on crosscountry synchronization, which can be due to increased trade or higher similarity of the legal economic environment.

\section{Conclusion}

The study of the business cycle synchronization using a year by year index gives new insights on the subject. Although our panel framework differs from the standard approach found in the literature, when we control for endogeneity, some of the results are in line with previous research. Bilateral trade and EU membership have a positive effect and industrial similarity is non-significant.

However, the reported negative effect of financial openness differs from standard cross section results. We think that the purposed panel framework unveils the short and medium term effects by controlling the long-run institutional factors in the time fixed effect component. This gives us a different perspective of the financial mechanism.

\section{References}

Arreaza, A., Sorensen, B., Yosha, O., 1998. Consumption smoothing through fiscal policy in OECD and EU countries. NBER Working Paper no. 6372.

Aviat, A., Coeurdacier, N., 2007. The geography of trade in goods and asset holdings. Journal of International Economics 71, 22-51.

Baxter, M., Kouparitsas, M., 2004. Determinants of business cycle commovement: a robust analysis. NBER working paper No. 10725.

Blundell, R., Bond, S., 1998. Initial conditions and moments restrictions in dynamic panel data models. Journal of Econometrics 87, 11-143.

Clark, T.E., van Wincoop, E., 2001. Borders and business cycles. Journal of International Economics 55, 59-85.

Deardorff, A., 1998. Determinants of bilateral trade: does gravity work in a neoclassical world. In: Frankel, J. (Ed.), The Regionalization of the World Economy. The University of Chicago Press, Chicago.

Frankel, J., Rose, A., 1998. The endogeneity of the optimum currency area criteria. Economic Journal 108, 1009-1025.

Honaker, J., King, G., 2007. What to do about Missing Values in Time Series Cross-Section Data. mimeo.

Imbs, J., 2004. Trade, finance, specialization and synchronization. Review of Economics and Statistics August 2004.

Imbs, J., 2006. The real effects of financial integration. Journal of International Economics 68 (2).

Kose, M., Prasad, E., Terrones, M., 2003. How does globalization affect the synchronization of business cycles. American Economic Review 93, 57-62.

Lane, P., Milesi-Ferretti, G.M., 2006. The external wealth of nations mark II: revised and extended estimates of foreign assets and liabilities, 1970-2004. CEPR Discussion Paper no. 5644.

Sorenson, B., Yosha, O., 1998a. International Risk Sharing and Industrial Specialization regional and international evidence. CEPR Discussion Paper no. 2295.

Sorenson, B., Yosha, O., 1998b. International Risk Sharing and European monetary unification. Journal of International Economics 45, 211-238.

Wooldridge, J.M., 2002. Econometric Analysis of Cross-Section and Panel Data. MIT Press, Cambridge Massachusetts.

\footnotetext{
${ }^{7}$ Although empirical evidence is at odds with the finance literature predictions, Aviat and Coeurdacier (2007) think that this "correlation puzzle" comes from endogeneity problems.
} 